T H E J O U R N A L O F T H E AMERICAN MEDICAL ASSOCIATION

I03 Dearborn Avenue :: :: Chicago, Ill. TELEPHONE, NORTH 717 CABLE adDRESS: "MEDIC, CHICAGO"

Subscription price: $\$ 5.00$ per annum in advance Foreign Subscription, including Postage, $£ 1$ 12s.

Postage in the United States and Canada, Cuba, Mexico, Hawail, Guam, 'orto Rico, and the Yhilippines, free; foreign postage, $\$ 2.50$. Subseriptions may commence at any time. Volumes begin with the Subseriptions may commence at any
fist issue of January and of July.

MEMBERSHIP IN THE AMERICAN MEDICAL ASSOCIATION.

The qualifications for membership require that the applicant be an active member of his county association if there is one. If there is none, membership in the state association or in one of its branches is necessaly. Applications must be accompanied with a certificate showing that the applicant is an active member of such recognized society, and should be sent with the annual dues-five dollars-to the AMERICAN MEDICAL Association, 103 Dearborn Avenue, Chicago. Members receive The Jounnal free. A subbership list without expense, provided his subscription for the fiscal year is paid.

FISCAL YEAR.

The fiscal year of the American MFdical Association is from January 1 to December 31 ; and the annual dues paid by a new member cover only the fiscal year, no matter at what time of year the membership is obtained. Those who pay their dues and join the Association at the annual meeting in June, for instance, pay only for the fiscal year which ends with the December following, and the annual dues for the following fiscal year are payable the succeeding January, at which time a statement is sent to each member. Such members, however, are entitled to

\section{ANONYMOUS COMMUNICATIONS.}

Anonymous communications, whether for publication, for infor. mation, or in the way of criticism, are consigned to the wastebasket unread.

\section{NEWS.}

Our readers are requested to send us Items of news of a medical nature, also marked copies of local newspapers contalning matters of interest to members of the medical profession. We shall be glad to know the name of the sender in every instance. The last forms of THE JoURnal are closed at $10 \mathrm{a}$. m. Wednesday, and all matter must be in before that time.

\section{ORIGINAL PAPERS.}

Articles are accepted for publication with the understanding that they are contributed solely to this journal.

\section{COPYRIGHT.}

Matter appearing In The Jounsal of THE AMERICAN MEDical AsSOCIATION is covered by copyright, but as a general thing. no objection will be made to the reproduction in reputable medical journals of anything rppearing in 1 ts columns if propel credit be given.

\section{CONTRIBUTIONS TYPEWRITTEN.}

It will be satisfactory to all concerned if authors will have their contributions typewritten before submitting them for publication. The expense is small to the author--the satisfaction is great to the editor and printer. We can not promise to return unused manu. script.

\section{ILLUSTRATIONS.}

Half-tones, zinc etchings and other lllustrations will be furnished by THF JoukNaL when photographs or drawings are supplled by the author.

\section{ADVERTISEMENTS.}

Advertising forms go to press eight days in advance of the date of issue. Therefore, in sending in copy, time snould be allowed for setting up advertisements and for the sending and return of proofs. Advertising rates will be made known on request.

\section{CHANGE OF ADDRESS.}

In ordering a change of address it is Important that both the old and new addresses be glven. Change should reach us not later than Ionday if following Saturday's issue is to be forwarded to new address.

\section{REMITTANCES.}

Remittances should be made by check, draft, registered letter, money or express order. Currency should not be sent, unless registered. Stamps in amounts under one dollar are acceptable. Make tered. checks, etc., payable to "A.MERICAX MEDICAL Association."

\section{PROSTATITIS.}

R. V. WAGNER, M.D.

Inventor and Designer of the Mica-Plate Static Machine and X-Ray Apparatus.

308 Dearborn Street, Chicago.

In the treatment of the prostatic portions of the urethra the High Frequency Induction Electrodes (commonly called ultra violet ray tubes) are peculiarly adapted to a number of conditions that are giving them great popularity in this class of work.

At first thought one would consider it extremely dangerous to introduce a long glass stem in the urethra, for fear of the same being broken off, but an examination of the toughness of the glass stem is convincing that there is no danger of this if reasonable care is exercised; however, where it is desired to take special precautions against such an accident, the glass stem may be covered with a membrane so that should it break, the parts could be easily withdrawn from the urethra by the membranous covering. The membranous covering will in no way interfere with the action of the tube.

Where acute inflammation exists in the urethra, it is not considered advisable to use the urethral electrodes, as the

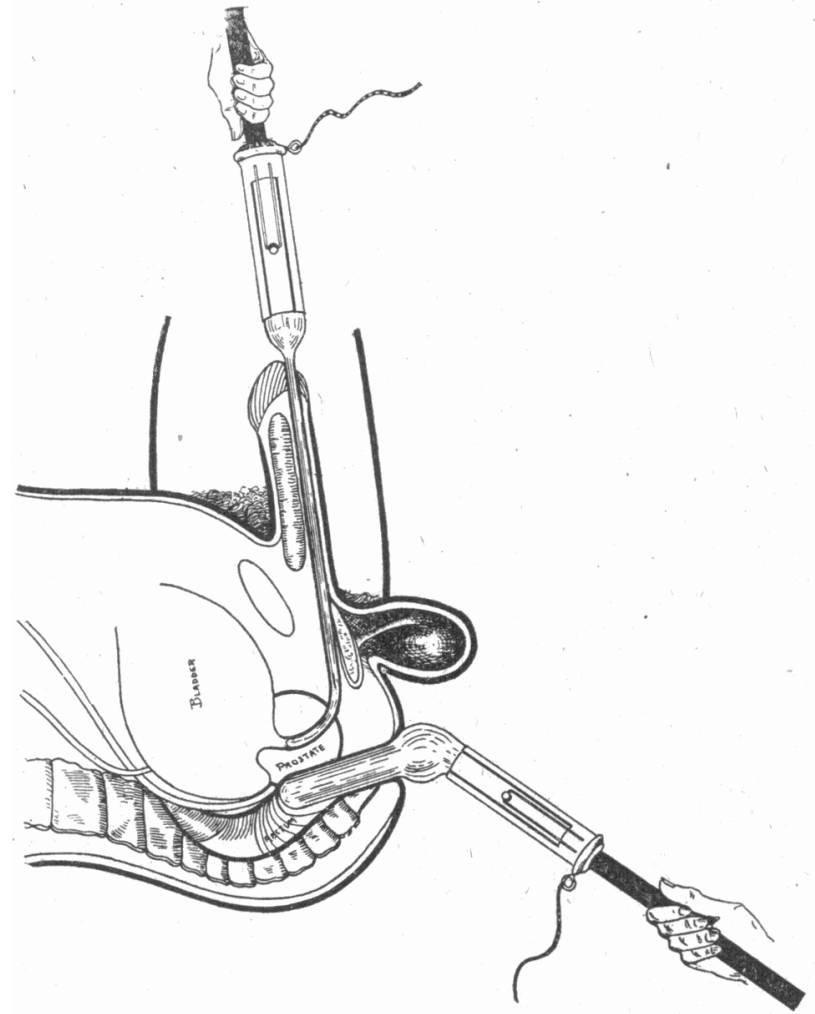

mechanical irritation caused by the introduction of the electrode is sufficient to off set the benefit which might be derived from the effects of the treatment tending to relieve infiammation and congestion.

Where acute inflammation is present, the best results:are obtained from the application of an electrode on the outside over the urethra. In prostatitis, and in inflamed conditions of the prostatic portions of the urethra, a rectal electrode is used with great success.

In using the rectal electrode, the tube should be excited with high enough tension current to produce a slight electrical sensation to the patient, the length of treatment generally employed being about ten minutes. In treating enlarged prostate, the use of urethral and rectal electrode, as per illustration, is most successful. Attach a rectal tube to one terminal of the high frequency apparatus, and the urethral to the other terminal; thus the inductive energy emanating from the tubes when placed in proper position is practically localized to the body of the prostate.

Every effort should be made to obtain high frequency high tension current for exciting the tube, as it must be remembered that the beneficial results depend upon the inductive energy emanating from the tube being sufficiently high in tension to decompose the oxygen in the tissue and to effect the structure of the cells themselves. 